\title{
Multiple small monthly doses of dicyandiamide (DCD) did not reduce denitrification in Waikato dairy pasture
}

\author{
NL Watkins ${ }^{\mathrm{a}}$, LA Schipper ${ }^{\mathrm{a}}$, GP Sparling ${ }^{\mathrm{a} *}$, B Thorrold ${ }^{\mathrm{b}}$ and M Balks ${ }^{\mathrm{a}}$ \\ ${ }^{a}$ Department of Earth and Ocean Sciences, University of Waikato, Hamilton, New Zealand; ${ }^{b}$ DairyNZ, \\ Hamilton, New Zealand
}

(Received 8 March 2012; accepted 1 October 2012)

\begin{abstract}
The effectiveness of multiple small doses of the nitrification inhibitor dicyandiamide (DCD) to decrease denitrification under warm moist conditions was tested in a 1-year field trial on a grazed dairy pasture. DCD was applied approximately every 4 weeks as an aqueous spray onto ten replicate plots 3 days after rotational grazing by dairy cows. Each application was at the rate of 3 $\mathrm{kg} \mathrm{DCD} \mathrm{ha}{ }^{-1}$, with a total annual application of $33 \mathrm{~kg} \mathrm{ha}^{-1}$. Denitrification was assessed 5 days after each DCD application using the acetylene block method. At the end of the trial, the rate of degradation of DCD under summer conditions was measured. DCD significantly decreased the mean annual nitrate concentration by about $17 \%$. Denitrification and denitrification enzyme activity were highly variable and no significant effect of DCD in decreasing denitrification was detected. In the summer month of December, DCD degraded rapidly with an estimated half-life of $5 \pm 3$ days (mean and standard deviation).
\end{abstract}

Keywords: denitrification; nitrous oxide; pastures; cattle urine; nitrification inhibitor; Dicyandiamide (DCD); New Zealand

\section{Introduction}

New Zealand is unusual among developed countries in that about half of the national greenhouse gas (GHG) emissions are produced from soil and animals in the rural sector rather than from urban industry and vehicles (MFE 2012). A further distinction is that $14.6 \%$ of total GHG emissions are attributable to nitrous oxide $\left(\mathrm{N}_{2} \mathrm{O}\right)$. Pastoral agriculture is the dominant agricultural land use in New Zealand, and $\mathrm{N}_{2} \mathrm{O}$ emissions from pastoral soils have increased by $23 \%$ since 2009 (MFE 2012). $\mathrm{N}_{2} \mathrm{O}$ is a particularly potent $\mathrm{GHG}$, being persistent in the atmosphere and with a 100-year global warming potential some 300 times greater than $\mathrm{CO}_{2}$ (MFE 2012). The main sources of $\mathrm{N}_{2} \mathrm{O}$ emissions from pastures are urine spots from grazing animals. Under New Zealand climate conditions, animals are normally kept on pasture the whole year and urine is thus consistently deposited directly on the soil (de Klein \& Ledgard 2005). Emissions of $\mathrm{N}_{2} \mathrm{O}$ from pastures are expected to increase due to the expansion in dairy farming, with larger dairy herds and higher stocking rates (SNZ 2012), coupled with greater use of $\mathrm{N}$ fertiliser (PCE 2004).

Nitrification inhibitors such as DCD (dicyandiamide) and $\mathrm{N}$-Serve (nitrapyrin) were originally intended to improve $\mathrm{N}$ retention in soil by blocking the microbial oxidation of ammonium to nitrate. However, the inhibitors also have the potential to alter other components of the nitrogen cycle such as denitrification. Saggar et al. (2007) suggest most $\mathrm{N}_{2} \mathrm{O}$ emitted from soil is formed during the

*Corresponding author. Email: sparling@waikato.ac.nz 
microbial process of denitrification; that is, when nitrate in soil, in the presence of a $\mathrm{C}$ substrate and low aeration, is partly denitrified by soil microbes to $\mathrm{N}_{2} \mathrm{O}$. Di \& Cameron (2008) showed that up to $40 \%$ of the $\mathrm{N}_{2} \mathrm{O}$ emitted from urine patches could be from nitrification, with $60 \%$ from denitrification. Substantial decreases in nitrate content and $\mathrm{N}_{2} \mathrm{O}$ emissions from New Zealand pasture soils with simulated urine spots treated with DCD were reported by Di \& Cameron (2005) and Di et al. (2007). There was an average $70 \%$ reduction in $\mathrm{N}_{2} \mathrm{O}$ from the simulated urine spots, following application of DCD in a fine particle suspension. In further work, Di \& Cameron (2008) showed DCD decreased $\mathrm{N}_{2} \mathrm{O}$ emissions during both nitrification and denitrification, resulting in a decrease of $72 \%$ in total emissions.

The persistence and effectiveness of DCD in soil are strongly influenced by soil temperature (Kelliher et al. 2008). Di \& Cameron (2004) reported a half-life of $111-116$ days at $8{ }^{\circ} \mathrm{C}$, which dropped to $18-25$ days at $20{ }^{\circ} \mathrm{C}$. Di \& Cameron (2004) suggested DCD would be most effective on well-drained soils in late autumn and spring, when soil temperatures would be less than $10{ }^{\circ} \mathrm{C}$. However, in a further study which included two soils and sites in North Island, Di et al. (2007) reported that DCD reduced $\mathrm{N}_{2} \mathrm{O}$ emissions by around $50 \%$ in both North Island and South Island sites. This was despite the generally warmer climate in the North Island Waikato region, although they did note that the weather pattern at the time of the trial had been unusually cool and dry.

If widespread use of DCD is to be encouraged to reduce $\mathrm{NO}_{3}$ leaching and/or $\mathrm{N}_{2} \mathrm{O}$ emissions, it is important to know what other aspects of the $\mathrm{N}$ cycle are affected by this compound. Denitrification is dependent on anaerobic conditions in the soil, available carbon and a sufficient supply of nitrate to act as electron acceptor. The authors were interested to test whether DCD would decrease denitrification (and hence $\mathrm{N}_{2} \mathrm{O}$ emissions) by limiting the nitrate supply during the warm and moist months typical of the Waikato region of
New Zealand. The Waikato region in North Island contains $30 \%$ of the national dairy herd (SNZ 2012) and hence is a major contributor to GHG emissions. It was reasoned that most denitrification would occur during spring and early summer when the soils are typically warm, moist and heavily stocked with cattle. Waikato has one of the highest cattle stocking rates of 2.96 cows per hectare (DairyNZ 2011). The soil temperature at $5 \mathrm{~cm}$ depth during the summer is $20-25{ }^{\circ} \mathrm{C}$ (Harris et al. 1999, Mudge et al. 2011), with a mean winter temperature of 13.6 ${ }^{\circ} \mathrm{C}$ (Environment Waikato 2006). These are within the range of soil temperatures used in a synthesis by Kelliher et al. (2008) to derive the temperature dependence of DCD degradation. If DCD can persist under warm and moist climate regimes, it was hypothesised that DCD would reduce denitrification by limiting the amount of nitrate available for denitrification.

This paper reports on a 12-month field study carried out on a grazed dairy pasture in the Waikato to determine the effectiveness of DCD in reducing denitrification. DCD was applied in multiple small doses approximately every 4 weeks at a rate equivalent to a total annual application of $33 \mathrm{~kg} \mathrm{ha}^{-1}$. This approach differs from that used by other researchers who have normally followed the recommendation that DCD be applied in two or three applications between autumn and late winter. The reason for using multiple monthly small doses was that rapid degradation of DCD during the summer months was anticipated and maintenance of a baseline concentration in the treated plots was sought. Also wanting the application method to follow normal farm practices, in contrast to other studies the plots were not irrigated following DCD application. Irrigation is not common practice in the Waikato region with less than 5000 ha of irrigated land. This contrasts greatly to other areas in New Zealand such as Canterbury where in 2009 there were an estimated 363,614 ha of irrigated land (New Zealand Government 2010). 
Rates of denitrification on treated and nontreated plots were assessed using the acetylene block technique and ancillary measures of soil nitrate and ammonium contents, soil moisture and temperature, respirable $\mathrm{C}$ and denitrifying enzyme activity (DEA). We also measured the persistence of DCD in the field during summer at the end of the trial.

\section{Methods}

\section{Field site and soil}

The field trial was located at the Scott Research Farm $\left(37^{\circ} 47^{\prime}, 175^{\circ} 19^{\prime}, 40 \mathrm{~m}\right.$ a.s.1.) managed by DairyNZ near Hamilton, New Zealand. The soil at the study site was a Horotiu silt loam derived from volcanic ash (Typic Orthic Allophanic Soil; Hewitt 1998). The Horotiu soils have medium to low dry bulk densities, moderate permeability and high phosphate retention. Typical Horotiu topsoil contains $8.2 \% \mathrm{C}, 0.75 \% \mathrm{~N}$, has a $\mathrm{pH}$ of 5.3 , total $\mathrm{P}$ of $2.4 \mathrm{~g} \mathrm{~kg}^{-1}$ and a bulk density of $0.8 \mathrm{Mg} \mathrm{m}^{-3}$ (Singleton 1991).

An experimental area for the DCD study was established on the control plots of a field experiment investigating grazing intensity, stocking rates, fertiliser use and supplementary feeds (Jensen et al. 2005). The control plots represented current average farming practice. The trial had been running since 2001 and carried 3.0 dairy cows per hectare, had an annual pasture production of $17.5 \mathrm{Mg}$ dry matter per hectare, was not irrigated and received $200 \mathrm{~kg} \mathrm{~N}$ fertiliser each year. The pasture composition was dominated by ryegrass, paspalum and white clover.

Soil moisture content at the field site was continuously measured using time domain reflectometery (TDR) model CS 625 (Campbell Scientific Inc.). Rainfall at the site was measured using a tipping bucket. A CR200 data logger collected the soil moisture content and rainfall data every 10 seconds; these data were averaged for over 30 minutes and stored for later use.

\section{Trial design}

Two treatments were used: (1) control pasture plots that were grazed and fertilised as described above; (2) treatment pasture plots that also received DCD. DCD was applied at the rate of $33 \mathrm{~kg} \mathrm{ha}^{-1} \mathrm{yr}^{-1}$ : this was similar to annual rates used in other New Zealand studies (e.g. Williamson et al. 1996, Di \& Cameron 2005). Twenty replicated field plots on a uniform area of pasture were established in a randomised plot design. Each plot measured 4 $\mathrm{m}$ by $4 \mathrm{~m}$ and had a $0.5 \mathrm{~m}$ guard strip between the plots. Each plot was randomly assigned one of the two treatments and there were ten replicates of each treatment. For each $4 \mathrm{~m}$ by $4 \mathrm{~m}$ plot, $4.8 \mathrm{~g}$ of DCD was dissolved in 5 litres of water (equivalent to $3 \mathrm{~kg}$ DCD ha ${ }^{-1}$ per application) and applied using a backpack sprayer. Plots receiving DCD were sprayed approximately every 4 weeks (Table 1), giving a total annual application of $33 \mathrm{~kg} \mathrm{ha}^{-1} \mathrm{yr}^{-1}$. DCD was usually applied 3-5 days after rotational grazing of the paddocks. However, depending on pasture growth, on some occasions rotational grazing was longer than the normal 20-25 day cycle (January, June and August) and in that case DCD was reapplied before grazing so as to maintain the weekly pattern (Table 2). The application of DCD 3 days after grazing was preferred as this ensured short pasture to maximise the quantity of DCD reaching the soil surface. Natural rainfall was used to wash any DCD on foliage into the soil. Monthly rainfall varied from 30 to $145 \mathrm{~mm}$, the driest months being September (31 $\mathrm{mm}$ ) and February (48 $\mathrm{mm}$ ) and the wettest May, August and January (139, 139 and $143 \mathrm{~mm}$ respectively).

Denitrification rates were measured 5 days after the application of DCD using the acetylene inhibition method described later.

\section{Degradation of DCD in the field}

Duplicate soil cores $2 \mathrm{~cm}$ diameter by $10 \mathrm{~cm}$ depth were collected in December 2006 from 
Table 1 Timetable indicating the dates cows grazed the field trial, dates of application of DCD $\left(3 \mathrm{~kg} \mathrm{ha}^{-1}\right)$ after grazing and dates of soil sampling 5 days after DCD application

\begin{tabular}{|c|c|c|c|}
\hline Sampling month (2006) & Cows grazed & DCD application & Sampling date \\
\hline January & 6 January & 12 January & - \\
\hline February & 22 January & 26 January & 1 February \\
\hline March & 19 February & 23 February & $1 \mathrm{March}$ \\
\hline April & Not sampled & Not sampled & Not sampled \\
\hline May & 22 April & 26 April & 2 May \\
\hline June & 26 May & 1 June & - \\
\hline July & 26 June & 30 June & 4 July \\
\hline August & 26 July & $1 \mathrm{Aug}$ & - \\
\hline September & 1 September & 5 September & 11 September \\
\hline October & 24 September & 28 September & 4 October \\
\hline November & 30 October & 3 November & 9 November \\
\hline December & 21 November & 5 November & 1 December \\
\hline
\end{tabular}

four replicate plots that had received DCD for 11 months previously. Cores were collected daily for the first 6 days following DCD application $\left(3 \mathrm{~kg} \mathrm{ha}^{-1}\right)$ and then every second day for a further 12 days. For each day, cores were further bulked to give two replicates per day. The cores were sieved to $<4 \mathrm{~mm}$, stored at $4{ }^{\circ} \mathrm{C}$ overnight and analysed for the presence of DCD as described below.

\section{Analytical methods}

Field measurements of in situ denitrification rates were made using the static soil core incubation system described by Ryden et al. (1987). Briefly, from each replicate plot, four intact soil cores (3.2 cm diameter, $16 \mathrm{~cm}$ depth) were collected using perforated PVC liners that allowed gaseous exchange. Four replicate cores were incubated in a 1.81 glass preserving jar fitted with a gas sampling septum. Acetylene was added to the jar to obtain $10 \% \mathrm{v} / \mathrm{v}$ concentration and mixed with the headspace air by flushing with a $60 \mathrm{ml}$ syringe. The jars were then placed in a temperature-controlled room set to the soil temperature at the time of sampling. Headspace gas samples $(22 \mathrm{ml})$ were taken from the jars $0.5,3,6$ and $24 \mathrm{~h}$ after the addition of acetylene, injected into Vacutainer tubes to obtain positive pressure and stored for subsequent analysis. The concentration of $\mathrm{N}_{2} \mathrm{O}$ in the headspace gas was obtained using a Philips gas chromatograph with an electron capture detector as described by Schipper et al. (2005). The accumulation of $\mathrm{N}_{2} \mathrm{O}$ in the presence of acetylene represents the total production of $\mathrm{N}_{2} \mathrm{O}$ and $\mathrm{N}_{2}$ from denitrification (Tiedje et al. 1989). Hourly denitrification rates were calculated from headspace concentration at each sampling time, and corrected for the solubility of $\mathrm{N}_{2} \mathrm{O}$ in the soil water using the temperature-dependent Bunsen absorption coefficients (Tiedje 1994).

Denitrifying enzyme activity (DEA) was measured following the methods of Tiedje et al. (1989). DEA is a commonly used method to determine relative amounts of microbes in soil capable of denitrifying (Tiedje et al. 1989). Soil $(10 \mathrm{~g})$ was incubated in $100 \mathrm{ml}$ Schott bottles in the presence of $20 \mathrm{ml}$ of glucose-nitrate solution

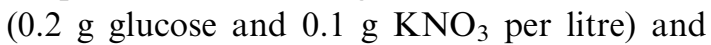
containing $0.125 \mathrm{~g}$ chloramphenicol per litre to prevent protein synthesis. The bottles were sealed with lids fitted with a gas sampling septum and flushed for 2 minutes with nitrogen gas. Acetylene $(10 \mathrm{ml})$ was added to inhibit the conversion of $\mathrm{N}_{2} \mathrm{O}$ to $\mathrm{N}_{2}$. The samples were incubated at $25^{\circ} \mathrm{C}$ on a rotary shaker and $5 \mathrm{ml}$ of headspace was removed after 15 and $75 \mathrm{~min}$ and injected into $3 \mathrm{ml}$ Vacutainer tube to generate 
Table 2 Monthly averages (ten replicates \pm standard error) of soil moisture content, temperature at $10 \mathrm{~cm}$ depth, respirable $\mathrm{C}$, ammonium and nitrate concentrations of Horotiu silt loam with and without amendment with DCD every 4 weeks at the rate of $3 \mathrm{~kg} \mathrm{ha}^{-1}$.

\begin{tabular}{|c|c|c|c|c|c|c|c|c|}
\hline \multirow[b]{2}{*}{ Month (2006) } & \multirow[b]{2}{*}{$\begin{array}{l}\text { Moisture content } \\
(\% \mathrm{w} / \mathrm{w})\end{array}$} & \multirow[b]{2}{*}{$\begin{array}{l}\text { Temperature at } \\
10 \mathrm{~cm} \text { depth }\left({ }^{\circ} \mathrm{C}\right)\end{array}$} & \multicolumn{2}{|c|}{$\begin{array}{c}\text { Respirable C } \\
\left(\mu \mathrm{CO}_{2}-\mathrm{C} \mathrm{g}^{-1} \mathrm{~h}^{-1}\right)\end{array}$} & \multicolumn{2}{|c|}{$\begin{array}{l}\text { Ammonium-N } \\
\left(\mu \mathrm{g} \mathrm{N} \mathrm{g}^{-1}\right)\end{array}$} & \multicolumn{2}{|c|}{$\begin{array}{l}\text { Nitrate-N } \\
\left(\mu \mathrm{g} \mathrm{N} \mathrm{g}^{-1}\right)\end{array}$} \\
\hline & & & Control & DCD & Control & DCD & Control & DCD \\
\hline January & 59.6 & 19 & $3.19 \pm 0.3$ & $3.91 \pm 0.2$ & $2.8 \pm 0.4$ & $3.0 \pm 0.3$ & $23.6 \pm 5.1$ & $32.3 \pm 6.6$ \\
\hline February & 65.4 & 23 & $5.84 \pm 0.6$ & $6.39 \pm 0.7$ & $6.3 \pm 0.6$ & $6.0 \pm 0.5$ & $51.5 \pm 8.2$ & $55.4 \pm 7.5$ \\
\hline March & 55.4 & 19 & $5.06 \pm 0.2$ & $5.31 \pm 0.4$ & $16.4 \pm 9.3$ & $22.9 \pm 9.8$ & $64.6 \pm 7.8$ & $58.2 \pm 6.1$ \\
\hline April & NT & NT & NT & NT & NT & NT & NT & NT \\
\hline May & 74.7 & 15 & $4.49 \pm 0.2$ & $3.96 \pm 0.2$ & $5.7 \pm 1.9$ & $9.8 \pm 2.6$ & $23.5 \pm 3.5$ & $19.7 \pm 1.8$ \\
\hline June & 79.9 & 10 & $4.55 \pm 0.5$ & $5.78 \pm 0.4$ & $1.4 \pm 0.2$ & $2.9 \pm 0.7$ & $4.6 \pm 0.5$ & $4.1 \pm 0.4$ \\
\hline July & 78.1 & 4 & $3.87 \pm 0.4$ & $3.91 \pm 0.3$ & $50.8 \pm 7.8$ & $63.5 \pm 6.4$ & $7.9 \pm 0.8$ & $5.1 \pm 0.4$ \\
\hline August & 74.0 & 12 & $2.98 \pm 0.2$ & $3.02 \pm 0.2$ & $21.0 \pm 4.2$ & $42.3 \pm 7.2$ & $17.6 \pm 3.0$ & $11.1 \pm 1.9$ \\
\hline September & 78.3 & 14 & $4.13 \pm 0.7$ & $4.33 \pm 0.4$ & $30.5 \pm 7.4$ & $46.5 \pm 7.2$ & $22.5 \pm 2.1$ & $8.5 \pm 0.8$ \\
\hline October & 79.8 & 15 & $4.24 \pm 0.4$ & $4.77 \pm 0.5$ & $26.7 \pm 11.3$ & $25.8 \pm 8.8$ & $17.4 \pm 3.7$ & $15.1 \pm 4.6$ \\
\hline November & 82.5 & 16 & $4.46 \pm 0.2$ & $4.46 \pm 0.4$ & $4.8 \pm 0.3$ & $5.7 \pm 0.5$ & $27.9 \pm 8.0$ & $15.1 \pm 2.0$ \\
\hline December & 76.9 & 16 & $3.34 \pm 0.6$ & $3.96 \pm 0.4$ & $8.6 \pm 0.4$ & $12.9 \pm 2.2$ & $43.5 \pm 7.2$ & $28.8 \pm 2.6$ \\
\hline Mean \pm SE & $73.1 \pm 0.63$ & $14.8 \pm 1.5$ & $4.20 \pm 0.15$ & $4.53 \pm 0.15$ & $15.9 \pm 2.14$ & $21.9 \pm 2.45$ & $27.7 \pm 2.27$ & $23.0 \pm 2.07$ \\
\hline
\end{tabular}

$\mathrm{NT}=$ not tested. 
positive pressure and stored for later analysis. The headspace gas samples were analysed for $\mathrm{N}_{2} \mathrm{O}$ as described earlier.

Analysis for DCD followed the method of Schwarzer \& Haselwandter (1996). Sieved soil samples were extracted by shaking $20 \mathrm{~g}$ dry weight equivalent with $100 \mathrm{ml}$ distilled water at $20{ }^{\circ} \mathrm{C}$ for $1 \mathrm{~h}$ on an end-over-end shaker. The sample was then centrifuged at $14,500 \mathrm{rpm}$ for 5 minutes, filtered through Whatman \#42 paper and frozen until subsequent analysis using a Shimadzu high-performance liquid chromatograph $($ HPLC), with a $300 \times 7.80 \mathrm{~mm}$ Aminex organic acid column HPX-87H.

Respirable $\mathrm{C}$ was estimated by incubating moist soil ( $35 \mathrm{~g}$ equivalent dry weight) in a sealed 1.81 preserving jar fitted with a gas sampling septum. The jars were incubated for 7 days at $25^{\circ} \mathrm{C}$ and the $\mathrm{CO}_{2}$ concentration in a sample of the headspace gas measured on a LiCor infra red gas analyser (Sparling \& Zhu 1993).

The total $\mathrm{C}$ and $\mathrm{N}$ content of the soil samples were determined by dry combustion on air-dry, finely ground soils using a Laboratory Equipment Corporation (LECO) TruSpec carbon/nitrogen determinator, using software version $1.6 \times($ LECO Corporation 2006).

Soil nitrate and ammonium concentrations were measured by shaking $10 \mathrm{~g}$ soil with $100 \mathrm{ml}$ of $2 \mathrm{M} \mathrm{KCl}$ for $1 \mathrm{~h}$ and filtering through Advantec 5C filter paper into extraction bottles. The samples were then frozen until subsequent analysis using standard AutoAnalyser methods (Blakemore et al. 1987). Soil $\mathrm{pH}$ was measured in a 1 part soil 2.5 parts water paste using a calibrated glass electrode as described by Blakemore et al. (1987). Soil moisture content was determined gravimetrically on each sampling date, from the weight loss of a sub-sample dried overnight at $105^{\circ} \mathrm{C}$ (Blakemore et al. 1987). Soil temperature was measured at a depth of $10 \mathrm{~cm}$ at $0830 \mathrm{~h}$ on the day of field sampling.

\section{Data analysis}

Analysis of variance (ANOVA) was performed on denitrification rates, ammonium and ni- trate concentrations, DEA, carbon availability and $\mathrm{pH}$ to determine whether there were significant differences $(P<0.05)$ between control plots and DCD-amended plots using Statistica version 7.1 (StatSoft Inc. 2007). Denitrification rates, DEA, and ammonium and nitrate data were log-transformed prior to analysis, while respirable $\mathrm{C}$ and soil $\mathrm{pH}$ values were squared prior to analysis to normalise the data.

\section{Results}

\section{Soil temperature and moisture}

Mean soil temperature at $10 \mathrm{~cm}$ depth was lowest $\left(5-10{ }^{\circ} \mathrm{C}\right)$ in the winter months of June and July and highest $\left(19-24{ }^{\circ} \mathrm{C}\right)$ in the summer months of January, February and March (Table 2). Rainfall was distributed throughout the year, but February $(48 \mathrm{~mm})$ and September $(31 \mathrm{~mm})$ were markedly drier than the other months. Ignoring those two dry months, the average rainfall was $117 \pm 26 \mathrm{~mm}$ per month (mean and SD). The soil moisture content fluctuated very little, remaining consistently around $73 \% \mathrm{w} / \mathrm{w}$ (Table 2).

\section{Denitrification}

Denitrification rates were highly variable. They were highest in November $\left(46-168 \mathrm{~kg} \mathrm{~N}^{-1}\right.$ $\mathrm{yr}^{-1}$ ) and lowest in January $(0.7-0.8 \mathrm{~kg} \mathrm{~N}$ $\left.\mathrm{ha}^{-1} \mathrm{yr}^{-1}\right)$. Annual rates of denitrification were $14 \pm 3.56 \mathrm{~kg} \mathrm{~N}^{-1}$ (mean and standard error, $n=110$ ) for the control plots and $28 \pm$ $8.26 \mathrm{~kg} \mathrm{~N}^{-1}$ for the DCD-treated plots. There were no significant differences between the two treatments at any of the sampling times (Fig. 1A).

\section{Denitrification enzyme activity}

DEA was highly variable, being greatest in summer (January) and least in August and September. Annual hourly rates were $311 \pm 38$ ng $\mathrm{N} \mathrm{g}^{-1}$ for the control plots (mean and standard error, $n=110$ ) and $368 \pm 48 \mathrm{ng} \mathrm{N} \mathrm{g}^{-1}$ 

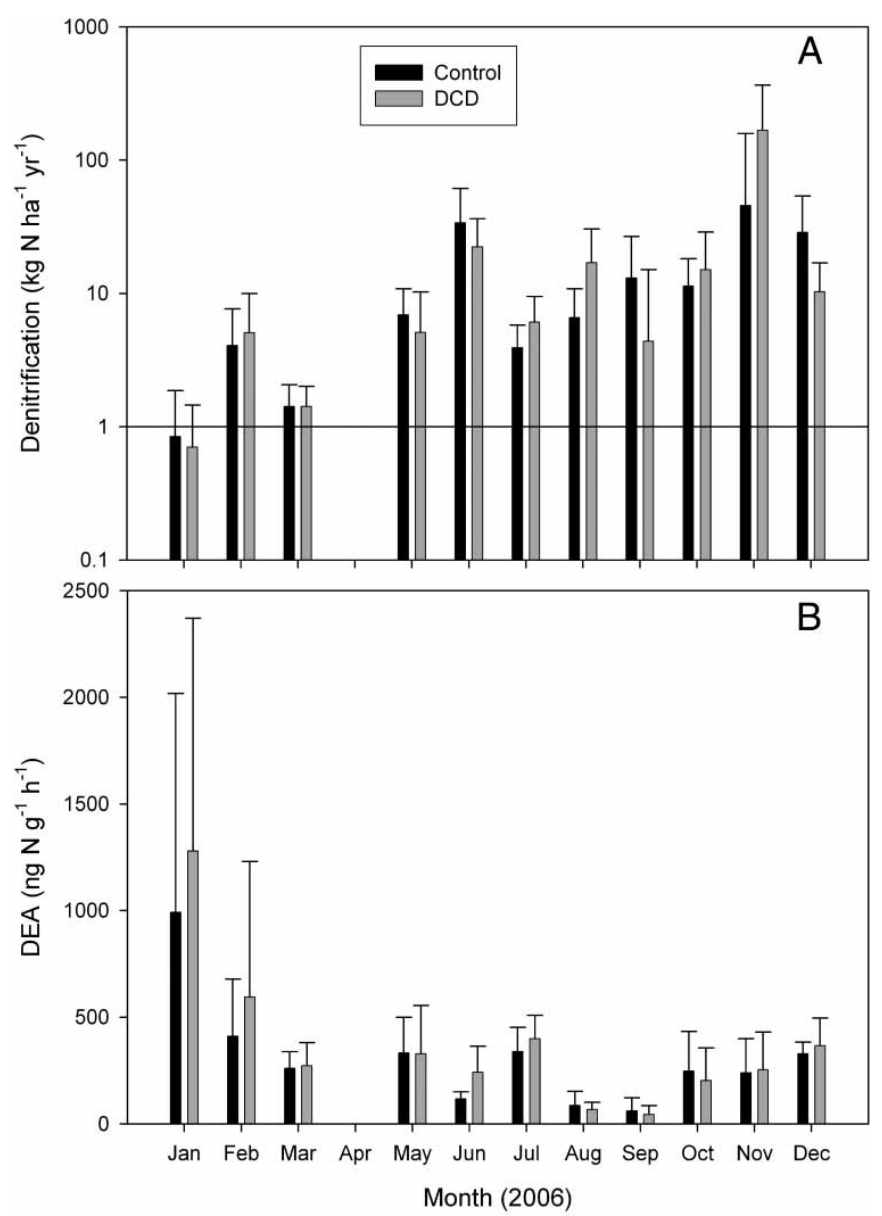

Figure 1 Monthly rates of $\mathbf{A}$ denitrification and $\mathbf{B}$ denitrification enzyme activity in grazed pasture plots receiving DCD at an annual rate of $33 \mathrm{~kg} \mathrm{ha}^{-1} \mathrm{yr}^{-1}$, applied every 3 weeks at the rate of $3 \mathrm{~kg} \mathrm{ha}^{-1}$, compared with non-treated control pasture plots. No sampling was done in April. Note logarithmic scale in graph A. Bars show standard error.

for the DCD-treated plots. There were no significant differences between the treatments at any of the sampling times (Fig. 1B).

\section{Respirable $\mathrm{C}$ and soil $\mathrm{pH}$}

Respirable $\mathrm{C}$ was reasonably constant throughout the year, fluctuating between 2.98 and $6.39 \mu \mathrm{g}$ $\mathrm{C} \mathrm{g}^{-1} \mathrm{~h}^{-1}$. There was no significant difference between the DCD and control plots (Table 2). Soil $\mathrm{pH}$ fluctuated between 5.5 and 6.4 , with no clear trend relating to season or treatment and no significant differences between treatments (data not presented).

\section{Ammonium and nitrate concentrations}

There was considerable seasonal variation in ammonium and nitrate concentrations (Table 2). Ammonium was generally higher in the winter months (July-September) while nitrate was generally higher in the summer (JanuaryMarch). Overall, ammonium-N concentrations were significantly greater $(P<0.01)$ on the 
plots receiving DCD (annual mean $21.9 \mu \mathrm{g} \mathrm{g}^{-1}$, compared to $15.9 \mu \mathrm{g} \mathrm{g}^{-1}$ on the control plots), and nitrate-N concentrations on the DCD plots were significantly $(P<0.01)$ lower than the controls (annual mean $23.0 \mu \mathrm{g} \mathrm{g}^{-1}$ on the DCD plots and $27.7 \mu \mathrm{g} \mathrm{g}^{-1}$ on the control plots).

\section{Degradation of DCD in the field}

The average soil temperature during December 2006 when the degradation study was undertaken was $16{ }^{\circ} \mathrm{C}$ at a soil depth of $10 \mathrm{~cm}$. In the first 2 days of the experiment, $3 \mathrm{~mm}$ of rain fell. The calculated amount of DCD added to the soil was $3.7 \mu \mathrm{g} \mathrm{g}^{-1}$ soil, assuming even distribution through the $10 \mathrm{~cm}$ soil depth. The amount recovered 1 day after application was $3.69 \mu \mathrm{g} \mathrm{g}^{-1}$ soil, representing almost full recovery $(99 \%)$ of the calculated amount. Beyond 1 day, the amount of DCD recovered declined in a logarithmic manner (Fig. 2) and after 15 days was no longer detectable. The half-life of DCD calculated for each of the sampled times over $0-15$ days, and using a starting concentration of $3.69 \mu \mathrm{g} \mathrm{g}^{-1}$ soil, was $5.5 \pm 3.2$ days (mean and standard deviation).

\section{Discussion}

In common with other studies (e.g. Thompson 1989; Di \& Cameron 2004, 2008) DCD changed the $\mathrm{N}$ cycle in grazed pasture soil; ammonium concentrations were significantly higher by around $38 \%$ and nitrate concentrations significantly lower by around $17 \%$ in the plots receiving DCD. However, this study did not detect any significant reduction in the monthly rates of denitrification or on DEA, despite the lower nitrate concentration. It has been hypothesised that a reduced level of nitrate in pasture plots receiving DCD would limit denitrification. This hypothesis was not supported, even though nitrate levels were lower in the plots receiving DCD. Ryden (1983) suggested that, for nitrate to limit denitrification, the concentration must be below $5 \mu \mathrm{g} \mathrm{NO}_{3}-\mathrm{N} \mathrm{g}^{-1}$. In the current study, the nitrate concentration fell below this value in only one month (June), even on the plots receiving DCD. For 10 of the 11 months sampled, nitrate concentrations were well above the $5 \mu \mathrm{g} \mathrm{NO}_{3}-\mathrm{N} \mathrm{g}^{-1}$ threshold and this is one reason why a decrease in denitrification was not detected.

Overall annual rates of denitrification (14-28 kg N ha ${ }^{-1}$ ) were close to the mean of $13 \mathrm{~kg} \mathrm{~N} \mathrm{ha}^{-1}$ reported by Barton et al. (1999)

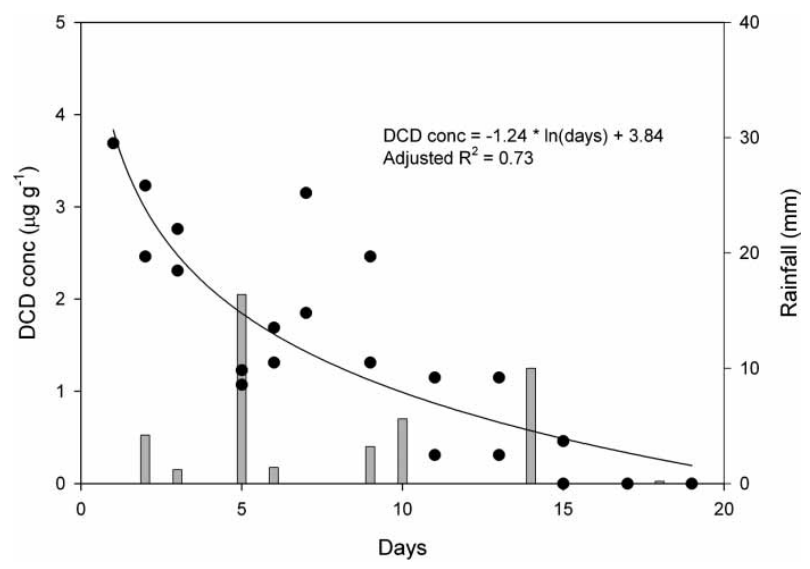

Figure 2 Degradation of DCD after application to dairy farm soils during the month of December fitted to an exponential decay curve $\left(\mathrm{DCD} \mu \mathrm{g} \mathrm{g}^{-1}=1.24 \ln\right.$ (days) +3.84$)$. Vertical bars show amount $(\mathrm{mm})$ and occurrence of rainfall. 
for agricultural soils. The generally low rate of denitrification could possibly be attributed to the moisture content of the soil, which was consistently around $70 \%$, and the soil may not have reached the waterfilled pore space of $62-$ $83 \% \mathrm{v} / \mathrm{v}$, above which denitrification is considered to be enhanced in loam soils (Barton et al. 1999).

The total annual amount of DCD applied (33 $\mathrm{kg} \mathrm{DCD} \mathrm{ha}{ }^{-1}$ ) in the study was at the upper end of the ranges of $10-30 \mathrm{~kg} \mathrm{ha}^{-1}$ used in other works (Merino et al. 2001, Cookson \& Cornforth 2002, Macadam et al. 2003) and considerably more than the $10-20 \mathrm{~kg} \mathrm{ha}^{-1}$ used in recent New Zealand studies by Di \& Cameron (2005) and Di et al. (2007). DCD has usually been applied in one or two large doses, and one difference with the current study was that the DCD was applied in multiple small doses of $3 \mathrm{~kg} \mathrm{ha}^{-1}$ every $3-4$ weeks. The intention was to maintain the concentration in surface soil to compensate for an anticipated rapid rate of degradation in the soil. However, Di \& Cameron (2005) reported that a single application of $5 \mathrm{~kg} \mathrm{DCD} \mathrm{ha}{ }^{-1}$ was not effective in obtaining the desired benefits on nitrification and denitrification. While the monthly rate of DCD application in this research was less than in other studies, the annual amount was greater; greater ammonium concentrations and lower nitrate concentrations were detected in the DCD plots, suggesting that DCD was at least partially effective at blocking nitrification. In contrast to these findings, Di et al. (2007) reported nearly $70 \%$ reduction in $\mathrm{N}_{2} \mathrm{O}$ emissions from a Waikato Horotiu soil when DCD was applied in two annual doses of $10 \mathrm{~kg} \mathrm{ha}^{-1}$, which suggests that the DCD was persistent and effective at reducing denitrification when applied at higher rates.

The rates of degradation of DCD in this study were very much faster than those reported in New Zealand literature. Di and Cameron (2004) reported that the half-life of DCD was $18-25$ days at $20{ }^{\circ} \mathrm{C}$ whereas, with an average field soil temperature at $10 \mathrm{~cm}$ depth of $16{ }^{\circ} \mathrm{C}$, the half-life is this study was 5.5 days.
Williamson et al. (1996) reported a half-life of 39 days at $22{ }^{\circ} \mathrm{C}$. Rajbanshi et al. (1992), working on soils in Germany, reported that between 10 and $30{ }^{\circ} \mathrm{C}$, the decomposition rate of DCD was doubled by a $10{ }^{\circ} \mathrm{C}$ rise in temperature and, at $30{ }^{\circ} \mathrm{C}$, half-lives were 2.9-11.5 days. The data from the current study fall within that latter range, although the temperature at $10 \mathrm{~cm}$ depth was about half of the maximum used by Rajbanshi et al. (1992).

This study relied on natural rainfall to wash any DCD retained on foliage into the soil, and the high recovery of DCD at early stages of the degradation experiment suggests that DCD had indeed been incorporated into the soil. However, it is possible that it was not distributed to the full depth of soil sampled and may have been retained in the top few centimetres. It is likely that the soil temperature in the top few centimetres of soil would have been considerably greater than the $16{ }^{\circ} \mathrm{C}$ measured in the Horotiu soil at $10 \mathrm{~cm}$ depth. Mudge et al. (2011) recorded surface soil temperatures $(5 \mathrm{~cm})$ at Scott Farm of $20-25{ }^{\circ} \mathrm{C}$ during summer and Harris et al. (1999) reported that the soil temperature during summer could reach a maximum of $36{ }^{\circ} \mathrm{C}$ at $5 \mathrm{~cm}$ depth. The surface Horotiu soil would also be likely to support a very active microbial population and to have a high organic matter content (Sarathchandra et al. 1984; Sparling et al. 2001). Organic matter can sorb DCD and reduce its effective concentration (Kelliher et al. 2008), and an active microbial community would assist with rapid degradation. The combination of a high soil temperature in the surface, DCD being retained in surface soil, organic matter sorption and rapid microbial degradation are likely explanations for the decline in DCD concentration and the shorter half-life than have previously been reported. The persistence of DCD for only 15 days during summer strongly suggests that for half of that month there would not have been any DCD present for it to be effective. Our estimate of a half-life of 5.5 days for DCD suggests that any month 
with a temperature greater than $25{ }^{\circ} \mathrm{C}$ in the surface soil could be expected to show a similar trend (Kelliher et al. 2008). The soil temperature at $10 \mathrm{~cm}$ depth fell below $10{ }^{\circ} \mathrm{C}$ in only one month (July) and was $15{ }^{\circ} \mathrm{C}$ or above for 7 months of the year.

A further complication in demonstrating any effects of DCD was the high variability in our dataset, which meant that differences between treatments were seldom significant. The plots were rotationally grazed by dairy cows and dung and urine was naturally deposited on the experimental plots. Such deposits are known to be randomly distributed, leading to highly variable concentrations of soluble nitrogen (Moir et al. 2011). Over a 12-month rotational grazing we would expect about a quarter of the plot surface to have received deposits of dung and urine. The soil sampling routine used here was random, but avoided obvious dung deposits. The high number of replicates and bulking of soil cores was intended to reduce this soil variability but, even so, on a monthly basis, no significant differences were detectable. It was only by combining all the monthly data that we were able to demonstrate significant annual differences in nitrate and ammonium concentrations between the DCD-treated and control plots.

The rapid degradation of DCD in the field, sorption to soil organic matter and our approach of using low monthly applications may be some reasons why DCD was only partly effective in blocking nitrification and hence limiting the supply of nitrate to the denitrifying microbes. In view of the apparently rapid degradation of DCD under summer conditions in this volcanic ash soil, to achieve a substantial reduction in nitrate levels and influence denitrification, it is likely that much larger amounts of DCD will need to be applied than used here, and several applications may still be required. Small monthly applications do not appear effective, even if the total annual application is large. Further work is needed to determine whether nitrification inhibitors will be sufficiently effective to limit denitrification under warm and moist climate conditions and whether such approaches are economically feasible and practical. The reliance on natural rainfall to wash DCD into soil also needs further investigation, as does the distribution of DCD through the soil following application to non-irrigated soils.

\section{Acknowledgements}

We thank DairyNZ and the Scott Farm managers and staff for access to the experimental site and day to day farm management. We thank AgResearch, Hamilton, for analysis of DCD. NTW acknowledges the receipt of a Technology Industry Fellowship from the Foundation of Research, Science and Technology, and the Whanganui River Enhancement Trust provided additional funding. Part of the work was funded by Landcare Research through contract CO9X0304 with the Foundation of Research, Science and Technology, and the University of Waikato. Anonymous reviewers provided helpful, detailed and constructive comments on the draft manuscript.

\section{References}

Barton L, McLay CDA, Schipper LA, Smith CT 1999. Annual denitrification rates in agricultural and forest soils: a review. Australian Journal of Soil Research 37: 1073-1093.

Blakemore LC, Searle PL, Daly BK 1987. Methods for chemical analysis of soils. New Zealand Soil Bureau Scientific Report 80: 9-31.

Cookson WR, Cornforth IS 2002. Dicyandiamide slows nitrification in diary cattle urine patches: effects on soil solution composition, soil $\mathrm{pH}$ and pasture yield. Soil Biology and Biochemistry 34: 1461-1465.

DairyNZ 2011. Table 3.1: Herd analysis by region in 2010/11. In: New Zealand dairy statistics 201011. Hamilton, DairyNZ. p. 14. http://www.lic. co.nz/pdf/DAIRY\%20STATISTICS\%2010-11WEB.pdf (accessed 8 November 2012).

de Klein CAM, Ledgard SF 2005. Nitrous oxide emissions from New Zealand agriculture - key sources and mitigation strategies. Nutrient Cycling in Agroecosystems 72: 77-85.

de Klein CAM, Cameron KC, Di HJ, Rys G, Monaghan RM, Sherlock RR. 2011. Repeated annual use of the nitrification inhibitor dicyandiamide (DCD) does not alter its effectiveness in reducing $\mathrm{N}_{2} \mathrm{O}$ emissions from cow urine. 
Animal Feed Science and Technology 166-167: 480-491.

Di HJ, Cameron KC 2004. Effects of temperature and application rate of a nitrification inhibitor, DCD, on nitrification rate and microbial biomass in a grazed pasture soil. Australian Journal of Soil Research 42: 927-932.

Di HJ, Cameron KC 2005. Reducing environmental impacts of agriculture by using a fine particle suspension nitrification inhibitor to decrease nitrate leaching from grazed pasture. Agriculture, Ecosystems and Environment 109: 202-212.

Di HJ, Cameron KC 2008. Sources of nitrous oxide from $15 \mathrm{~N}$-labelled animal urine and urea fertilizer with and without a nitrification inhibitor, dicyandiamide (DCD). Australian Journal of Soil Research 46: 76-82.

Di HJ, Cameron KC, Sherlock RR 2007. Comparison of the effectiveness of a nitrification inhibitor, dicyandiamide, in reducing nitrous oxide emissions in four different soils under different climatic and management conditions. Soil Use and Management 23: 1-9.

Environment Waikato 2006. About the Waikato region. www.ew.govt.nz (accessed 22 December 2006).

Harris SL, Waugh CD, McCabe RJ, van Vught VT 1999. Effect of deferred grazing during summer on white clover content of Waikato dairy pastures, New Zealand. New Zealand Journal of Agricultural Research 42: 1-7.

Hewitt AE 1998. New Zealand soil classification. 2nd edn. Lincoln, Canterbury, Manaaki Whenua Press.

Jensen RN, Clark DA, MacDonald KA 2005. Resource Efficient Dairying trial: measurement criteria for farm systems over a range of resource use. Proceedings of the New Zealand Grassland Association 67: 47-52.

Kelliher FM, Clough TJ, Clark H, Rys G, Sedcole JR. 2008. The temperature dependence of dicyanamide (DCD) degradation in soils: a data synthesis. Soil Biology and Biochemistry 40: 1878-1882.

LECO Corporation 2006. Truspec CN carbon/nitrogen determinator instruction manual. Michigan, USA, LECO Corporation.

Macadam X, Prado A, Merino P, Estavillo J, Pinto M, Gonzalez-Murua C 2003. Dicyandiamide and 3,4-dimethyl pyrazole phosphate decrease nitrous oxide emissions from grassland but dicyandiamide produces deleterious effects in clover. Journal of Plant Physiology 160: $1517-1523$.

Merino P, Estavillo JM, Besga G, Pinto M, Gonzalez-Murua C 2001. Nitrification and denitrification derived nitrous oxide production from a grassland soil under application of DCD and Actilith F2. Nutrient Cycling in Agroecosystems 60: 9-14.

MFE (Ministry for the Environment) 2012. New Zealand's greenhouse gas inventory 1990-2010. Publication no. ME 1095. Table ES3.1.1, p. 33. Wellington, New Zealand, MFE.

Moir JL, Cameron KC, Di HJ, Fertsak U 2011. The spatial coverage of dairy cattle urine patches in an intensively grazed pasture system. Journal of Agricultural Science 149: 473-485.

Mudge PL, Wallace DF, Rutledge S, Campbell DI, Schipper LA, Hosking CL 2011. Carbon balance of an intensively grazed temperate pasture in two climatically contrasting years. Agriculture, Ecosystems and Environment 144: 271-280.

New Zealand Government. 2010. Rural water infrastructure: Table 26, Irrigated area (ha) by region. In: National infrastructure plan, March 2010. Wellington: New Zealand Treasury. p. 122. http://infrastructure.govt.nz/plan/mar 2010/53.htm (accessed 8 November 2012).

PCE (Parliamentary Commissioner for the Environment) 2004. Growing for good; intensive farming, sustainability and New Zealand's Environment. Parliamentary Commissioner for the Environment, Wellington, New Zealand.

Rajbanshi SS, Benckiser G, Ottow JCG 1992. Effects of concentration, incubation temperature, and repeated applications on degradation kinetics of dicyandiamide (DCD) in model experiments with silt loam soil. Biology and Fertility of Soils 13: 61-64.

Ryden JC 1983. Denitrification loss from a grassland soil in the field receiving different rates of nitrogen as ammonium nitrate. Journal of Soil Science 34: 355-365.

Ryden JC, Skinner JH, Nixon DJ 1987. Soil core incubation system for the field measurement of denitrification using acetylene-inhibition. Soil Biology and Biochemistry 19: 753-757.

Saggar S, Hedley CB, Giltrap DL, Lambie SM 2007. Measured and modeled estimates of nitrous oxide emission and methane consumption from sheep-grazed pasture. Agriculture Ecosystems and Environment 122: 357-365.

Sarathchandra SU, Perrott KW, Upsdell MP 1984. Microbiological and biochemical characteristics of a range of New Zealand soils under established pasture. Soil Biology and Biochemistry 16: 177-183.

Schipper LA, Barkle GF, Vojvodic-Vukovic M 2005. Maximum rates of nitrate removal in a detritrification wall. Journal of Environmental Quality 34: 1270-1276. 
Schwarzer C, Haselwandter K 1996. Rapid quantification of the nitrification inhibitor dicyandiamide in soil samples, nutrient media and bacterial cell-free extracts. Journal of Chromatography A 732: 390-393.

Singleton PL 1991. Soils of Ruakura - a window on the Waikato. DSIR Land Resources scientific report no. 5. Lower Hutt, New Zealand, DSIR.

Sparling GP, Zhu C 1993. Evaluation and calibration of methods to measure microbial biomass $\mathrm{C}$ and $\mathrm{N}$ in soils from Western Australia. Soil Biology and Biochemistry 25: 1793-1801.

Sparling GP, Schipper LA, Russell JM 2001. Changes in soil properties after application of dairy factory effluent to New Zealand volcanic ash and pumice soils. Australian Journal of Soil Research 39: 505-518.

StatSoft Inc. 2007. Electronic statistics textbook. Oklahoma, USA, StatSoft Inc. http://www.statsoft.com/textbook/stathome.html (accessed 24 October 2012).

SNZ (Statistics New Zealand) 2012. Agricultural production statistics June 2010. http://www. stats.govt.nz/browse_for_stats/industry_sectors/ agriculture-horticulture-forestry/Agricultural Production_HOTPJun10final.aspx (accessed 24 October 2012).

Thompson RB 1989. Denitrification in slurry-treated soil: occurrence at low temperatures, relationship with soil nitrate and reduction by nitrification inhibitors. Soil Biology and Biochemistry 21: $875-882$.

Tiedje JM 1994. Denitrifiers. In: Methods of soil analysis part 2, microbiological and biochemical properties - SSSA book series no. 5. Madison, WI, USA, Soil Science Society of America, pp. $245-267$.

Tiedje JM, Simkins S, Groffman PM 1989. Perspectives on measurement of denitrification in the field including recommended protocols for acetylene based methods. Plant and Soil 115: 261-284.

Williamson JC, Menneer JC, Torrens RS 1996. Impact of dicyandiamide on the internal nitrogen cycle of a volcanic, silt loam soil receiving effluent. Applied Soil Ecology 4: 39-48. 